\title{
A LEGITIMIDADE AD CAUSAM PARA OS INTERDITOS POSSESSÓRIOS CONTRA MOLÉSTIAS DA POSSE PRATICADAS NO SISTEMA TIME-SHARING
}

\author{
LEGITIMACY FOR REPOSSESSION AGAINST DISSEISIN \\ PRACTICED IN THE TIME-SHARING SYSTEM
}

\author{
GILBERTO FACHETTI SILVESTRE ${ }^{1}$ \\ JOÃo Victor PEREIRA CASTELLO ${ }^{2}$ \\ JULIA DE CARLI BAIÔCCO 3
}

\section{RESUMO}

Trata-se de pesquisa que questionou e investigou como é a tutela da posse no caso de esbulho, turbação e ameaça praticados contra coproprietário no regime de multipropriedade (time-sharing) dos arts. 1.358-B a 1.358-N do Código Civil. Para isso, a pesquisa trabalhou com duas situações hipotéticas: a primeira é o caso de moléstia praticada por terceiro, ou seja, por pessoa estranha ao negócio jurídico de multipropriedade; e a segunda diz respeito à possibilidade de a moléstia ser praticada por um dos coproprietários contra outro em específico ou contra todos os demais. Para confirmar a hipótese, a pesquisa precisou discutir, preliminarmente, sobre a possibilidade ou não de desdobramento da posse (direta e indireta) no time-sharing, demonstrando que há sim essa possibilidade, tanto no viés teórico quanto no prático. Para alcançar esses objetivos, a pesquisa procedeu a uma revisão bibliográfica qualitativa para, dedutivamente, confirmar a hipótese de desdobramento da posse e de moléstia praticada entre coproprietários.

PALAVRAS-CHAVE: Multipropriedade. Esbulho possessório. Interditos possessórios. Legitimidade ativa. Liminar possessória.

1 Professor do Departamento de Direito e do Programa de Pós-Graduação em Direito (Mestrado em Direito Processual) da Universidade Federal do Espírito Santo (UFES); Doutor em Direito Civil pela Pontifícia Universidade Católica de São Paulo (PUC/SP); Mestre em Direito Processual Civil pela Universidade Federal do Espírito Santo (UFES); Coordenador dos Grupos de Pesquisa "Desafios do Processo" e "Medicina Defensiva" (PPGDIR/UFES); Advogado. Lattes: http://lattes.cnpq. br/7148335865348409. ORCID: https://orcid.org/0000-0003-3604-7348. E-mail: gilberto.silvestre@ufes.br.

2 Mestrando em Direito Processual Civil da Universidade Federal do Espírito Santo (UFES); Pesquisador do Grupo de Pesquisa "Desafios do Processo". ORCID Id: https://orcid.org/0000-0003-0074-5363. E-mail: joaov.castello@hotmail.com.

3 Acadêmica de Direito da Universidade Federal do Espírito Santo (UFES); Pesquisadora do Grupo de Pesquisa "Desafios do Processo". E-mail: judecarlib@hotmail.com. interditos possessórios contra moléstias da posse praticadas no sistema time-sharing. Revista Meritum, Belo Horizonte, vol. 15, n. 3, p. 52-72, Set./Dez. 2020. DOI: https://doi.org/10.46560/meritum.v15i3.8109. 
It is a research that questioned and investigated how is the protection of possession in the case of disseisin practiced against co-owners in the time-sharing regime of arts. 1.358-B to 1.358- $\mathrm{N}$ of the Civil Code. For this, the research worked with two hypothetical situations: the first is the case of a disseisin practiced by a third party, that is, by a person outside the time-sharing contract; and the second concerns the possibility of the disseisin being practiced by one of the co-owners against another specifically or against all the others. To confirm the hypothesis, the research had to discuss, preliminarily, about the possibility or not of the split of possession (direct and indirect) in time-sharing, demonstrating that there is such a possibility, both in theoretical and practical bias. In order to achieve these objectives, the research carried out a qualitative bibliographic review to deductively confirm the hypothesis of the split of possession and disseisin practiced among co-owners.

KEYWORDS: Time-sharing. Disseisin. Repossession. Legitimacy. Possessory injunction.

\section{INTRODUÇÃO}

Esta é uma pesquisa que objetiva averiguar como se dá a tutela interdital possessória no regime de multipropriedade, especificamente sobre os direitos de multipropriedade instituídos pela Lei $\mathrm{n}^{\circ}$. 13.777/18, a qual acrescentou ao Código Civil os arts. 1.358-B a 1.358-N. Se alcançado esse objetivo, o resultado será a solução de dúvidas não apenas quanto à legitimidade ad causam na tutela possessória, mas também permite compreender a incidência do regime jurídico da posse sobre a multipropriedade. A pesquisa constatou que há poucos trabalhos que tratam especificamente da multipropriedade no seu aspecto possessório.

O manejo adequado da tutela interdital proporciona evidente vantagem ao tutelado que poderá ser beneficiado com o eventual deferimento de liminar inaudita altera pars na ação possessória de força nova. Para tanto, parte-se do direito material, fazendo-se necessário uma abordagem conceitual e teórica sobre as moléstias da posse aplicada sobre o regime de multipropriedade que inova com a divisão da propriedade em frações temporais, em vez do tradicional conceito de divisão de propriedade em frações espaciais.

A problemática se evidencia exatamente diante da peculiar divisão da propriedade em frações temporais, pois implica, consequentemente, no modo e no momento que os multiproprietários exercem a posse. Por conseguinte, surgem dúvidas na ocorrência de conflitos possessórios, especificamente no que tange a possibilidade de moléstia entre os multiproprietários, bem como na hipótese em que o exercício da posse de um coproprietário é limitado por terceiro (penitus extraneus), na qual indaga-se quem seria a parte legítima para figurar no polo ativo da ação possessória.

A partir da análise do desdobramento da posse, foi possível encontrar a resposta para o problema apresentado, de forma que, teoricamente, os multiproprietários estarão na posse da coisa, seja diretamente, enquanto exercem o domínio pleno sobre a coisa enquanto a utilizam durante o período pré-estabelecido, bem como quando não exercem poder diretamente sobre a coisa, pois seriam titulares da posse indireta.

Não obstante, enquanto titulares da posse indireta, os multiproprietários devem abster-se de utilizar o imóvel, em obediência ao período pré-estabelecido na convenção existente entre os multiproprietários. Assim, se os multiproprietários são sempre possuidores, eles 
poderiam sofrer moléstia a qualquer tempo, portanto podendo se valer da tutela interdital mesmo que não estejam na posse direta do imóvel e em face de qualquer pessoa, mesmo que seja outro o titular do gozo da multipropriedade naquela fração de tempo.

Ainda, ao aprofundar na análise das moléstias e no desdobramento da posse, abordou-se as hipóteses de autotutela e o papel do administrador, como fâmulo, na ocorrência de uma moléstia, o que permitiu uma análise da tutela interdital em maior âmbito. Outrossim, ao adentrar mais especificamente na legitimidade ativa interdital possessória, propõe-se a possibilidade de o administrador representar os interesses dos multiproprietários em juízo, em analogia ao regramento que trata do condomínio edilício.

Por conseguinte, foi possível constatar a legitimidade ativa de todos os multiproprietários para a heterotutela possessória - que imprescindivelmente perpassa pelo desdobramento da posse -, para, assim, propor interditos possessórios com o objetivo de fazer cessar a moléstia da posse.

Para atingir o resultado da pesquisa optou-se pelo método dedutivo, de forma que com o aprofundamento dos estudos das moléstias e desdobramento da posse dentro da multipropriedade fosse possível extrair premissas teóricas e exemplos práticos que confirmassem a hipótese aventada.

\section{AS MOLÉSTIAS DA POSSE NA MULTIPROPRIEDADE}

O regime de time-sharing pressupõe a existência de diferentes proprietários para uma mesma coisa, seja ela móvel ou imóvel, de modo que a divisão entre eles ocorre em frações temporais alternadas, e não em frações espaciais tal e qual ocorre no condomínio edilício (ALPA, 1998, p. 193-200) (PÉREZ, 1992, p. 25 e ss.) (CASTRO, 1989, p. 10 e ss.).

Em se tratando de coisas imóveis, tem-se a vinculação dos proprietários ao negócio jurídico (testamento ou convenção) de instituição dessa modalidade sui generis de condomínio (art. 1.358-F do Código Civil), cabendo a um administrador (trustee) - que faz as vezes de síndico ou cabecel - controlar o imóvel e suas instalações, equipamentos e mobiliário, conforme o caput do art. 1.358-M.

Apesar de ser um modo de exercício da propriedade, com características peculiares, na multipropriedade podem ocorrer limitações ao exercício da posse pelos multiproprietários, a ponto de às vezes ficar configurada a existência de moléstia da posse praticada por um dos proprietários perante os demais (CERVALE, 2014, p. 358-370) (BERNAT, 1992, p. 50). É para a verificação dessa possibilidade e para descobrir como combatê-la que se destinaram as investigações da presente pesquisa.

No Brasil, três são os tipos de moléstias da posse: o esbulho, a turbação e a ameaça (caput do art. 1.210 do Código Civil) (SILVESTRE, 2019, p. 340) (LINS, 1914, p. 155-174). No que tange à sua prática por terceiros, não são verificadas mudanças significativas em relação à propriedade tradicional, ou seja, aquela em que não há fracionamento periódico, exceto quanto à discussão sobre a legitimidade ativa. 
A moléstia praticada por terceiro - ou seja, por um penitus extraneus ao negócio jurídico multiproprietário - ocorre quando uma pessoa que não é proprietária no condomínio comete atos que impedem o exercício pleno da posse pelo coproprietário, seja pela retirada do possuidor da coisa, seja por atos que embaraçam o livre exercício da posse ou, ainda, seja pelo risco consistente de um futuro esbulho ou turbação. Nesses casos, o molestador não possuirá posse legítima do imóvel perante os multiproprietários, sendo cabível a propositura da tutela interdital possessória para a proteção e defesa da posse (SILVESTRE, 2019, p. 340350).

Em virtude dos chamados desdobramentos da posse, essas ações podem ser propostas por qualquer dos multiproprietários, tendo em vista que todos guardam a qualidade de possuidores, mesmo aqueles que não estejam no exercício do usufruto cíclico, pois nesta hipótese manterão a posse indireta. A posse se desdobra em direta e indireta, de modo que o possuidor direto exerce um contato físico imediato sobre o bem, enquanto o indireto media esse contato por meio de um negócio jurídico (art. 1.197 do Código Civil) (PENTEADO, 2014, p. 622).

Esse desdobramento, no entanto, "não anula a proteção possessória que deve ser deferida a cada um dos titulares da situação possessória" (PENTEADO, 2014, p. 622), de modo que tanto o possuidor direto como o indireto podem defender sua posse contra terceiros, ou mesmo contra outro possuidor.

A existência de um acordo nomogenético do time-sharing entre os multiproprietários pressupõe a concordância dos titulares em utilizar o imóvel apenas em sua unidade periódica, abstendo-se do uso no turno dos demais multiproprietários (SMORTO, 1999, p. 279) (MARQUES, 1998, p. 23). Então, há distribuição dos poderes possessórios entre eles, decorrentes do negócio jurídico e que divide a posse em direta e indireta.

A posse direta do imóvel no âmbito da multipropriedade é exercida no momento em que o proprietário está legitimamente fruindo de sua fração temporal.

0 art. 1358-E elenca que o período correspondente a cada unidade de tempo poderá ser fixo e determinado, flutuante ou misto. 0 sistema fixo impõe que a posse será exercida pelo proprietário sobre o mesmo período de tempo a cada ano. Assim, ficam previamente estabelecidos o dia e a hora de entrada e saída dos multiproprietários de suas unidades periódicas. No regime flutuante, por outro lado, a determinação do lapso temporal de cada titular será realizada de maneira periódica, não ocorrendo necessariamente na mesma época do ano. Por fim, o misto combina os dois sistemas, mesclando suas características.

Seja qual for o sistema adotado no condomínio multiproprietário, o exercício de todos os poderes inerentes à propriedade simultaneamente se dá apenas no lapso temporal convencionado, momento em que o titular terá a posse direta do imóvel (DE COS, 2011, p. 44) (BARDAJÍ, 2000, p. 1429). Contudo, isso não retira a qualidade de possuidor do proprietário que não está no uso e na fruição, já que "a posse direta, de pessoa que tem a coisa em seu poder, temporariamente, em virtude de direito pessoal, ou real, não anula a indireta, de quem aquela foi havida, podendo o possuidor direto defender a sua posse contra o indireto" (art. 1.197 do Código Civil).

De modo diverso ocorre na composse ( $\S 2^{\circ}$ do art. 73 do Código de Processo Civil). Aqui, a divisão da propriedade ocorre no próprio espaço físico do imóvel e os proprietários 
exercem a posse em conjunto, impondo a necessidade de participação de ambos em uma possível demanda judicial. Não há desdobramento da posse em direta e indireta, vez que elas ocorrem simultaneamente.

Já o regime de time-sharing divide a coisa em unidades periódicas: cada coproprietário exerce a posse sobre a totalidade do imóvel durante determinado lapso temporal, de modo que não há repartição do espaço físico em si (DE COS, 2011, p. 44) (BARDAJÍ, 2000, p. 1429).

A divisão da posse em direta e indireta garante que a proteção possessória em face de terceiro seja invocada por qualquer dos possuidores, conforme o art. 1.197 do Código Civil. Dessa forma, os interditos possessórios podem ser propostos por qualquer dos multiproprietários, uma vez que a legitimidade ad causam decorre da qualidade de possuidor da coisa, conforme o inciso I do art. 561 c/c art. 560, ambos do Código de Processo Civil: para propor a ação possessória o autor precisa comprovar sua posse, ou seja, provar que é possuidor; e as formulações normativas falam somente em "posse" e "possuidor", sem especificar se se trata da direta ou da indireta.

Portanto, neste regime, em se tratando de legitimidade ativa para a tutela interdital em face de terceiro molestador, o litisconsórcio ativo não será necessário, e sim facultativo, garantindo aos multiproprietários a liberdade de demandar sem impor a obrigação de integrar a lide.

Nas moléstias praticadas entre os coproprietários, as regras de caracterização do esbuIho, da turbação e da ameaça, e a consequente proteção possessória, são diferenciadas quando comparadas com a situação de terceiro molestador.

Primeiramente, registre-se que os incisos VII e VIII do caput do art. 1.358-J do Código Civil criam as obrigações do multiproprietário de usar o imóvel exclusivamente em sua fração temporal e desocupá-lo até a data fixada na instituição ou na convenção de condomínio.

O descumprimento desses deveres, além de acarretar o pagamento da multa convencionada, configurará esbulho, que consiste no ato pelo qual o possuidor será privado de exercer a posse. A origem do esbulho pode estar em algum ato praticado mediante violência, clandestinidade ou precariedade (abuso de confiança) (AVENDAÑO VALDEZ, 1986, p. 59-63) (GONÇALVES, 2008, p. 151 e ss.), nos termos o art. 1.200 do Código Civil.

Assim sendo, v.g., o proprietário que continua utilizando o imóvel após encerrada sua fração de tempo, ameaçando com violência física (ameaça de lesão ou morte) o titular que deseja exercer sua posse e as faculdades inerentes à sua propriedade, pratica esbulho. Isso porque, nesse momento, o proprietário que se recusa a devolver o bem não tem a posse legítima da coisa, tendo em vista que permanece ilicitamente na unidade periódica de outro coproprietário. Terá, assim, posse injusta (MACCORMACK, 1974, p. 71-80) (RICCOBONO, 2012, p. 1-10) (FERRETTI, 2020, p. 11-36).

Frise-se que esse esbulho será praticado apenas contra o proprietário que está no direito de usar o imóvel, já que este será o único possuidor impedido de exercer a sua posse. Os demais multiproprietários não são legítimos para utilizar a coisa na fração temporal de outro titular, o que faz com que esse impedimento não os atinja de forma direta.

Apesar disso, o esbulho consiste em uma ameaça à posse dos próximos proprietários, vez que não há garantia de que a moléstia cessará quando encerrada a unidade periódica em 
que está ocorrendo. Se persistir, concretizando a ameaça, restará caracterizado o esbulho contra o proprietário da fração temporal seguinte. Além disso, não deixa de ser uma moléstia contra sua posse indireta.

Pode ainda o proprietário da multipropriedade praticar o esbulho quando, percebendo que outro titular não está utilizando sua fração temporal correspondente, invade o imóvel para dele usufruir (SIQUEIRA e SIQUEIRA, 2017, p. 65). Caracteriza-se a moléstia, nessa hipótese, portanto, pela existência da clandestinidade.

Outro exemplo diz respeito ao esbulho pacífico, resultante do vício da precariedade. Esse caso pode ser verificado quando o proprietário, tendo conhecimento de que o titular da unidade seguinte não utilizará o imóvel e abusando da confiança nele depositada, permanece utilizando-o como se fosse o proprietário daquela fração temporal. (Ou seja, basicamente: não entrega a coisa ao próximo proprietário com direito de usar).

Quanto à turbação, cuida-se de atos sobre a coisa ou ações que dificultam ou embaraçam o livre exercício da posse, de modo que o turbado continua a possuir, porém a extensão do poder fático que exerce resta limitada pela prática da moléstia (GONÇALVES, 2019, p. 151). Pode a moléstia ocorrer de maneira direta, quando ocorre imediatamente sobre a coisa, ou indireta, quando - apesar de praticada externamente - repercute sobre a coisa possuída (GONÇALVES, 2019, p. 151).

A título de exemplo de perturbação direta, tem-se a hipótese em que um dos multiproprietários causa perturbação ao legítimo possuidor da fração temporal atual, por meio de ligações telefônicas ou mensagens questionando quando ele deixará o imóvel; ou, também hipoteticamente, realiza visitas inesperadas que geram incômodo e desequilíbrio na relação negocial estabelecida.

Quanto à turbação indireta, pode ser observada no momento em que o turbador, sabendo que outro proprietário deseja locar o imóvel em sua respectiva fração temporal, pratica atos para impedir ou dificultar a disposição da coisa.

Pois bem. Ainda quanto às moléstias da posse praticadas pelos próprios multiproprietários entre si, há que se destacar que o art. 1.358-J do Código Civil prevê multa caso o titular ultrapasse o tempo estabelecido na instituição ou na convenção do condomínio em time-sharing. Mas essa multa terá caráter indenizatório. Por isso, é facultado também ao(s) coproprietário(s) recorrer(em) ao juízo possessório para a proteção de sua(s) posse(s). Nesse caso, ressalte-se que é imprescindível a condição de possuidor, seja direto ou indireto, para obter a legitimidade ad causam (inciso I do art. 561 c/c art. 560, ambos do Código de Processo Civil). No polo passivo, por outro lado, deve figurar o sujeito responsável pelo esbuIho, pela turbação ou pela ameaça.

Além disso, tal e qual no caso de ocorrência de esbulho ou turbação na posse em situações gerais, quando há violência ou clandestinidade será admitida, também, a autotutela possessória, por meio da legítima defesa da posse e do desforço imediato. Nessa hipótese, o próprio possuidor pratica atos pela própria força para defender sua posse e afastar a moléstia à qual está sendo submetido, sem a necessidade de se valer do processo judicial.

Para isso, o $\S 1^{\circ}$ do art. 1.210 do Código Civil dispõe que o ato defensivo de própria força deve ser praticado "logo". Sendo assim, o possuidor, em legítima defesa da posse, tem o direito de praticar atos de violência contra o esbulhador logo no momento em que a moléstia 
está ocorrendo ou, agindo em desforço imediato, logo após ter ocorrido. Entretanto, esta violência reativa deve ser proporcional àquela verificada na moléstia, ou seja, somente o necessário para impedir a moléstia.

Agir em circunstâncias diferentes destas, como em tempo muito posterior ao conhecimento da moléstia ou com excesso de violência, pode configurar o crime de exercício arbitrário das próprias razões (art. 345 do Código Penal) e motivar uma indenização pelos danos causados.

Além disso, cabe ao administrador vistoriar o interior da unidade para constatar se não houve danos ao imóvel e se ele está em condições de uso pelo legítimo titular da fração temporal seguinte.

Se verificada a permanência do titular, mesmo quando findada sua respectiva fração de tempo, fica a cargo também do administrador, de imediato, praticar atos para recuperar a posse, fazendo uso da autotutela para defender os interesses comuns dos condôminos (MENDO, 2009).

Recorda-se da autotutela, na maioria das vezes, apenas no caso de violência contra a coisa, que autoriza a ação do possuidor por meio de força própria. Todavia, deve-se ter em mente que impedir o legítimo possuidor de ingressar no imóvel também é uma espécie de violência.

A posse justa pressupõe, além da ausência de violência e clandestinidade, que não haja precariedade (art. 1.200 do Código Civil). A posse precária é aquela que se inicia justa, mas passa a ser injusta por ato de abuso de confiança praticado pelo possuidor que, finda a posse concedida, se recusa a restituir a coisa, transformando-se em detentor e esbulhador ipso facto (COSTA, 1998, p. 113).

Essa hipótese envolve a resistência do esbulhador em desocupar o imóvel ou uma intimidação por parte dele para impedir que o legítimo possuidor ingresse na propriedade. Pode ser feito por meio da troca de fechaduras, ameaças verbais ou mesmo da obstrução da passagem, portando-se como barreira para impedir a entrada.

Configura-se, então, por uma violência física ou moral, bem como através da clandestinidade. Logo, a autotutela é cabível também no caso de posse precária, vez que a posse que era justa e autorizada passa a configurar uma moléstia contra a posse do legítimo possuidor.

Nesse sentido, tanto o administrador como o proprietário da fração temporal em que está ocorrendo a moléstia podem agir em autotutela. Entretanto, cumpre analisar se os outros multiproprietários, que terão uso futuro do imóvel e mantêm a posse indireta sobre ele, são legitimados para reagir em autodefesa da posse.

$0 \S 1^{\circ}$ do art. 1.210 do Código Civil não especifica se a autotutela será exercida pelo possuidor direto ou indireto, afirmando genericamente que o "possuidor" turbado ou esbulhado poderá manter-se ou restituir-se por sua própria força. Por não haver restrição legal, é admitido seu exercício por ambos os possuidores. É possível, ainda, que o detentor - o fâmulo ou servo do art. 1.198 ou o autorizado do art. 1.208, ab ovo - pratique esses atos de autotutela em benefício do possuidor. (A propósito, no caso do fâmulo, ele está lá justamente para isso).

O possuidor indireto, nesse sistema, apesar de ceder o contato físico sobre o bem ao possuidor direto conforme um negócio jurídico, permanece proprietário do imóvel, guar- 
dando legitimidade para defender seu patrimônio quando observar que seu domínio está sendo molestado.

No regime de multipropriedade imobiliária, todavia, os titulares detêm a propriedade de uma fração temporal, e não apenas do espaço físico em si. Existe, então, uma limitação do direito de propriedade quanto ao seu exercício, de modo que o esbulho praticado contra um proprietário não se estenderá aos demais multiproprietários (TRANCHANT, 2014, p. 276) (SANDRI, 2014, p. 79). Em relação a eles, a moléstia em questão constitui uma ameaça.

A formulação normativa do $\S 1^{\circ}$ do art. 1.210 é clara ao afirmar que apenas o possuidor turbado ou esbulhado poderá defender a sua posse por sua própria força, não sendo admitida a autotutela quando o possuidor está diante de uma ameaça. Portanto, poder-se-ia imaginar que apenas o proprietário da unidade periódica que está sendo esbulhada poderia agir em legitima defesa da posse ou em desforço imediato.

Aos outros multiproprietários, que aguardam seus respectivos turnos para usar a coisa, caberia apenas a via judicial, por meio da ação de interdito proibitório no juízo possessório, sob pena de infringir a lei civil.

Então, ao encerrar a unidade temporal do titular que estava sendo molestado e iniciar o turno do próximo proprietário, aquele que estava diante de uma ameaça passaria a ver sua posse em situação de esbulho. Todavia, o $\S 1^{\circ}$ do art. 1.210 do Código Civil é explícito ao determinar que a reação seja "logo", não sendo possível agir em autotutela após o decurso de um lapso temporal considerável.

Sendo assim, se o turno do próximo proprietário se iniciasse em momento próximo à ocorrência da moléstia, poderia manter-se ou restituir-se por sua própria força. Caso contrário, sua única saída seria a heterotutela possessória, através da atuação do Poder Judiciário.

A prevalecer esse entendimento, o possuidor indireto deveria optar entre observar uma moléstia ocorrendo em sua posse, sem poder fazer nada para impedir, ou recorrer à justiça, podendo esperar por meses ou anos uma resposta judiciária.

Não bastasse isso, apesar de o possuidor indireto estar diante de uma ameaça à sua posse direta, não se trata apenas de um temor, tal e qual ocorre na propriedade tradicional. O esbulho está de fato ocorrendo contra a posse, não se trata de uma mera possibilidade.

Quando a lei criou o desdobramento da posse, o objetivo foi justamente garantir a legitimidade do possuidor indireto para sua defesa, seja pela heterotutela, seja pela autotutela. Isso se torna extremamente necessário para assegurar que o titular exerça as faculdades decorrentes da propriedade de maneira livre e desembaraçada.

Por não haver nenhuma restrição legal para a defesa da posse através da própria força pelo possuidor indireto, não é compatível exigir que o coproprietário assista um esbulho ou turbação ocorrendo em sua posse e aguarde seu turno para agir. Ou então, exigir que ele ajuíze uma ação possessória e fique exposto à demora da justiça, podendo ver a coisa prejudicada em decorrência do tempo, quando poderia impedir os danos.

Quanto à heterotutela, poder-se-ia sustentar, ainda, que a efetividade do interdito possessório seria concretizada pela concessão da medida liminar.

O caput do art. 562 do Código de Processo Civil prescreve que, se a petição inicial estiver devidamente instruída, o juiz deferirá, sem ouvir o réu, a expedição do mandado liminar de 
manutenção ou de reintegração. Para isso, exige-se apenas que o autor tenha provado sua posse, a turbação ou esbulho praticado pelo réu, bem como a data de ocorrência, e a continuação ou perda da posse, a depender da moléstia (art. 561 do Código de Processo Civil).

Além disso, se o proprietário houver proposto o interdito proibitório - por se tratar de uma ameaça à sua futura posse direta - e a moléstia vier a se concretizar, tornando-se de fato um esbulho ou turbação, aplicar-se-ia a fungibilidade interdital, transformando a ação em reintegração ou manutenção da posse (art. 554 do Código de Processo Civil) e, hipoteticamente, garantindo a eficiência da tutela jurisdicional.

Então, se o juiz restar superficialmente convencido, com base em uma cognição incompleta, determinará, de ofício, a alteração do interdito proibitório para manutenção ou restituição da posse, a depender da moléstia verificada, concedendo a liminar possessória apropriada e prosseguindo-se no rito ordinário (GONÇALVES, 2019, p. 159 e 173).

Todavia, a liminar inaudita altera pars exige que a ação seja de força nova, com posse decorrente de moléstia ocorrida em até um ano e um dia da data do esbulho ou da turbação. Então, se o titular utilizar a coisa somente após decorrido esse período, perderá o benefício do procedimento especial e, consequentemente, a antecipação da tutela sem a oitiva da parte contrária.

Nesse sentido, a fungibilidade dos interditos possessórios e a medida liminar nem sempre garantirão a ele o exercício das faculdades inerentes à propriedade desde o início de seu turno, tendo como resultado, inúmeras vezes, um processo judicial que não traz um desfecho eficaz para o possuidor.

A enorme quantidade de processos judiciais, constantemente sem resolução adequada e definitiva, aliada à morosidade da justiça, fez com que o ordenamento jurídico buscasse soluções alternativas para a resolução de controvérsias, como a mediação, a conciliação e a arbitragem, bem como a desjudicialização - fenômeno que desloca algumas atividades que eram atribuídas ao Poder Judiciário para o âmbito das serventias extrajudiciais (MARQUES, 2020).

Portanto, é evidente o objetivo de, sempre que possível, decidir as questões fora da esfera judicial, prezando por reduzir a quantidade de litígios nos tribunais, que estão cada vez mais abarrotados, e garantir a efetividade na esfera do direito material.

Nessa lógica, é compatível que o possuidor possa defender sua posse sem que tenha que recorrer ao Poder Judiciário, haja vista que a efetividade da justiça deve ser buscada não apenas no âmbito dos processos judiciais, como também nas soluções extrajudiciais.

Deve-se garantir o resultado mais adequado, tempestivo, eficiente e com menos custos ao Poder Judiciário - objetivando, também, evitar a enorme quantidade de processos nas varas e nos tribunais e a economia processual.

Assim, assegura-se um resultado mais célere e efetivo ao possuidor na defesa da posse, sem prejuízo aos demais multiproprietários ou a outros sujeitos da relação jurídica.

Finalmente, a terceira moléstia da posse é a ameaça, provocada por atos que causam um justo receio de sobrevir um esbulho ou turbação, conforme caput, in fine, do art. 1.210 do Código Civil c/c art. 567 do Código de Processo Civil. Para tanto, o ato deverá ser objetivamente considerado, isto é, ser capaz de provocar temor em uma pessoa comum, em virtude 
de condutas que indicam iminência e inevitabilidade de ocorrência das moléstias (GONÇALVES, 2019, p. 170-171).

Exempli gratia, tem-se o caso do proprietário que afirma que não entregará o imóvel na data e horário previstos na instituição ou convenção do condomínio time-sharing. Pratica, desse modo, ameaça, ato que pode levar à proposição de uma ação possessória de caráter preventivo - qual seja, o interdito proibitório -, a fim de impedir a concretização de tal intimidação.

De acordo com Carlos Roberto Gonçalves (2019, p. 172), o interdito proibitório se assemelha à ação cominatória, pois prevê a condenação pecuniária para evitar que a ameaça seja consumada. A partir do pedido do autor e a fixação pelo juiz de um montante razoável, objetiva-se desestimular o réu intimidador a prosseguir com o ato. Mas, se ainda assim, no decorrer do processo, a ameaça iminente se concretizar, essa ação será transmudada para a manutenção ou reintegração da posse (a depender da moléstia verificada).

Assim, é verdade que o proprietário é, de fato, titular do imóvel em determinada época do ano, podendo utilizar a coisa livremente em sua respectiva unidade periódica. Entretanto, encerrada a sua fração temporal, tornar-se-á tão molestador quanto um terceiro que nenhuma relação possui com a coisa, uma vez que impede que o próximo legítimo possuidor da unidade periódica exerça de maneira livre e desembaraçada as faculdades decorrentes de sua propriedade.

Registre-se, ainda, que no âmbito do condomínio edilício, são recorrentes nos tribunais de apelação ações que indicam a ocorrência de esbulho, turbação e ameaça praticados pelo síndico. A título de exemplo, os seguintes julgados: TJRJ, Ap. Cível $n^{\circ}$ 0032149-80.2015.8.19.0014, 22ª Câmara Cível, Rel. Des. Marcelo Lima Buhatem, julgado em 06/08/2019; TJSP, Ap. Cível n 1001933-25.2017.8.26.0477, $27^{\text {a }}$ Câmara de Direito Privado, Rel. Des. Alfredo Attié, julgado em 17/06/2019; TJRS, Ap. Cível n 70080816424, 20ª Câmara Cível, Rel. Des. Glênio José Wassserstein Hekman, julgado em 10/04/2019.

Isso ocorre quando ele, por exemplo, impede a entrada de um proprietário no imóvel em razão do atraso no pagamento das despesas condominiais por iniciativa pessoal. Neste caso, age em exercício arbitrário das próprias razões, e não em obediência a qualquer regra do condomínio ou deliberação da assembleia (que, ainda que exista, será ilegal).

Em uma interpretação analógica, verifica-se que as moléstias da posse também podem ser cometidas pelo administrador do imóvel objeto da multipropriedade.

Como exemplo de atos que embaraçam o exercício livre e pleno da posse, cita-se o caso em que o administrador, assim como o síndico do condomínio edilício, não permite que um proprietário entre no imóvel, apesar de estar diante de sua legítima unidade temporal, ou, então, restrinja o uso in totum do imóvel. Há também a hipótese em que o administrador ameaça reter a coisa caso o titular não pague uma despesa referente à sua manutenção. 0 administrador pode, ainda, trocar a fechadura da porta de entrada do imóvel e utilizar a fração de tempo correspondente a um proprietário.

Então, o administrador do time-sharing, assim como terceiros e os próprios multiproprietários, podem praticar moléstias da posse e, consequentemente, figurarem no polo passivo das ações possessórias. 


\section{A LEGITIMIDADE ATIVA INTERDITAL POSSESSÓRIA NA MULTIPROPRIEDADE MOLESTADA: MOLÉSTIA POR PENITUS EXTRANEUS E POR COPROPRIETÁRIO}

A heterotutela da posse em caso de esbulho, turbação e ameaça ocorre por meio dos interditos possessórios (ou ações possessórias), quais sejam, reintegração de posse, manutenção na posse e interdito proibitório (IHERING, 2007, p. 30 e ss.).

Nesse contexto, é de se questionar a quem pertence a legitimidade para propor essas ações nos casos de time-sharing.

Os arts. 1.358-B a 1.358-N, incluídos no Código Civil pela Lei $\mathrm{n}^{\circ}$. 13.777/2018, não trataram expressamente sobre esse assunto. Mas, como o art. 1.358-B determina a aplicação subsidiária do regime jurídico condominial edilício (Lei nº 4.591/1964) à multipropriedade, e como naquela modalidade de propriedade o manejo das ações possessórias é comum, pode-se solucionar as dúvidas sobre os interditos em sede de time-sharing a partir da experiência forense cotidiana do condomínio edilício.

Conforme o inciso II do caput do art. 1.348 do Código Civil, no condomínio edilício o síndico é responsável por representar o condomínio edilício nos atos extrajudiciais e judiciais, por meio de ações necessárias à defesa do interesse comum.

Em uma interpretação por analogia, por ser o administrador responsável pela a administração do condomínio multiproprietário e de suas instalações, equipamentos e mobiliário (art. 1.358-M), é válido equipará-lo à figura do síndico (OLIVEIRA, 2020a). Ademais, essa legitimidade processual é repetida pelo inciso XI do caput do art. 75 do Código de Processo Civil.

Nessa perspectiva, cabe ao administrador, também, representar os interesses do condomínio multiproprietário em juízo ou fora dele, ativa e passivamente, inclusive em ações de caráter possessório.

Todavia, a representação pelo administrador seguirá o mesmo regime jurídico do condomínio edilício. 0 gestor deve ter conhecimento de que não deve agir por conta própria e de acordo com seus desejos pessoais, mas sim em conformidade com as pretensões comuns e legítimas dos multiproprietários, nos moldes da convenção de condomínio ou deliberação da assembleia.

É válido concluir, então, que o administrador possui, por si só, legitimidade ad causam para propor interditos possessórios e figurar no polo ativo da demanda, bem como para agir na proteção direta da posse por meio da autotutela.

E quanto aos multiproprietários, guardam eles legitimidade ativa para a heterotutela interdital possessória?

Destaca-se, em primeiro lugar, como faculdades constitutivas do direito de propriedade, os direitos de usar, usufruir, dispor e reivindicar. No âmbito da multipropriedade imobiliária, as faculdades de usar e gozar são limitadas à fração de tempo de cada adquirente, porém não dizem respeito apenas à estrutura física do imóvel (PAIVA, 2020). 0 titular da unidade 
periódica possui amplos poderes sobre o espaço e quaisquer instalações, equipamentos e mobiliários que dela façam parte.

Entretanto, é vedado aos coproprietários a realização de quaisquer atividades que alterem ou deteriorem a unidade, até mesmo benfeitorias, conforme dispõe o inciso IV do caput do art. 1.358-J do Código Civil. Do contrário, restaria evidente a intromissão na propriedade dos demais titulares do imóvel.

Nos mesmos moldes, o direito de dispor da propriedade está restrito à fração de tempo do proprietário, conferindo ampla liberdade ao titular para ceder seu direito de uso e fruição, bem como transferir ou alienar a coisa a outrem. Seguindo esta lógica, Gustavo Tepedino (1993, p. 103) conclui que: "Vale, portanto, para a multipropriedade, o princípio pelo qual nemo plus juris in alium transferre potest quam ipse habet: o uso, o gozo e a disposição da coisa limitam-se à extensão espaço-temporal do objeto do direito, reduzido aos confins da unidade habitacional no turno determinado e expresso inequívoca e visualmente no calendário".

Já quanto ao poder de reivindicar a coisa (jus vindicandi), trata-se da proteção da propriedade, ou seja, do direito de reivindicá-la de quem injustamente a possua ou a detenha, por meio da ação reivindicatória (GONÇALVES, 2019, p. 226).

De acordo com Gustavo Tepedino (1993, p. 58-59 e 124), a multipropriedade imobiliária se apresenta como uma relação jurídica de aproveitamento econômico do imóvel, repartida em unidades fixas de tempo, de maneira que os multiproprietários utilizam a coisa com exclusividade durante seu turno.

Nesta senda, torna-se evidente que esta modalidade fraciona a coisa por unidades de tempo em que o titular poderá utilizar o imóvel, e não o espaço físico em si.

Pela Lei $n^{\circ}$. 13.777/2018 o regime de multipropriedade foi introduzido no Código Civil como um direito real, confirmando o entendimento já aplicado pela Terceira Turma do Superior Tribunal de Justiça no julgamento do Recurso Especial n 1.546.165/SP (STJ, REsp. $\mathrm{n}^{\circ}$ 1.546.165/SP, $3^{a}$ Turma, Rel. Min. Ricardo Villas Bôas Cueva, Rel. p/ acórdão Min. João Otávio de Noronha, julgado em 26/04/2016). Assim dispõe o caput do art. 1.358-C do Código Civil, in verbis: "Art. 1.358-C. Multipropriedade é o regime de condomínio em que cada um dos proprietários de um mesmo imóvel é titular de uma fração de tempo, à qual corresponde a faculdade de uso e gozo, com exclusividade, da propriedade imóvel, a ser exercida pelos proprietários de forma alternada. [...]".

Logo, sobre a multipropriedade devem recair todas as características referentes aos direitos reais, inclusive o direito de sequela, do qual decorre o poder de reivindicar a coisa de quem injustamente a detenha (ALARCÓN e ALARCÓN, 1995, p. 20).

Ademais, entende-se a perpetuidade como um direito sem vencimento, isto é, que existe mesmo que o titular não o exerça. Nesta linha, Gustavo Tepedino destaca:

De tais considerações decorre o caráter real da multipropriedade imobiliária. O vínculo jurídico que se instaura adere imediatamente ao bem imóvel sobre o qual incide, servindo o contrato, embora imprescindível, unicamente para definir o objeto do direito e disciplinar a relação entre os multiproprietários, e entre estes e a empresa promotora, à qual é delegada a função de gerir o imóvel. Entretanto, a recíproca limitação (espaço-temporal) de poderes 
não é fator de intermediação, senão de mera coordenação e demarcação de esferas jurídicas, não retirando, pois, a natureza real do direito do multiproprietário, com prevalência erga omnes. [...]. Se o direito de propriedade incide exclusivamente sobre o turno, a projeção do direito individual sobre o todo é, ao contrário, universal, atingindo todos os recantos do imóvel, ainda que em intensidade diminuta [...]. A co-titularidade sobre as partes comuns assegura ao multiproprietário a composse do solo, ainda que sua posse seja apenas indireta naqueles períodos estranhos ao seu turno (TEPEDINO, 1993, p. 58-9, 124).

Assim, o direito de propriedade é perpétuo quanto à duração, embora temporário quanto ao exercício. A perpetuidade garante a permanência desse direito independentemente de ser colocado ou não em prática, ou seja, ele é imprescritível pela ausência de exercício das faculdades.

Então, o coproprietário possui o direito de reivindicar a coisa mesmo que não esteja inserido na unidade de tempo a ele atribuída, principalmente se observada a possibilidade de perda da propriedade pela usucapião. Todavia, por óbvio, não poderá reivindicá-la do proprietário que esteja legitimamente fruindo de sua fração temporal, sendo admitida apenas se proposta em face de terceiro molestador.

Além das ações reivindicatórias (juízo petitório), decorrentes da propriedade, cumpre analisar aquelas resultantes da posse, a saber a reintegração da posse, a manutenção na posse ou o interdito proibitório.

A posse é passível de possuir desdobramentos, causados pela distribuição autorizada dos poderes inerentes a ela para dois ou mais possuidores.

A posse direta sobre as frações temporais ocorre de maneira alternada, ou seja, cada proprietário a exercerá durante um lapso temporal fixado no instrumento de instituição ou na convenção de condomínio em multipropriedade. Então, o exercício de todos os poderes decorrentes de sua propriedade simultaneamente estará restrito a este período.

Contudo, considerando que possuidor é "todo aquele que tem de fato o exercício, pleno ou não, de algum dos poderes inerentes à propriedade", nos termos do art. 1.196 do Código Civil, a posse não se restringe àquele que está legitimamente fruindo de sua fração temporal.

O proprietário que não está na posse direta da coisa permanece com a qualidade de possuidor, vez que continua exercendo o poder de reivindicar a coisa - ainda que limitado ao terceiro molestador.

A legitimidade ad causam do proprietário que não tem contato material com o imóvel o corpus, no sentido da teoria subjetiva de Friedrich Karl von Savigny - se justifica, portanto, pela posse indireta, tendo em vista que o ato de entregar a coisa ao titular da fração temporal seguinte não implica a perda da posse, apenas o desdobramento em indireta.

Assim sendo, o coproprietário, embora não tenha a posse direta, poderá fazer uso do juízo possessório, já que uma posse não anulará a outra (art. 1.197 do Código Civil). Ambas passam a coexistir no tempo e no espaço, de modo que tanto o possuidor direto como o indireto podem invocar proteção possessória contra terceiro, bem como utilizá-la um contra o outro. 
Desse modo, se verificada a ocorrência de uma moléstia da posse na unidade periódica de um dos multiproprietários, os demais também terão legitimidade para propor ação possessória. Exempli gratia, tendo que o esbulho verificado na unidade periódica atual torna-se uma ameaça àquele que irá ocupar o imóvel na próxima fração temporal, bem como para os demais multiproprietários, há legitimidade e interesse de todos os titulares para propor interditos possessórios, com objetivo de fazer cessar essa moléstia da posse.

Entender o contrário seria admitir que o coproprietário que irá ocupar o imóvel no próximo período de tempo tenha suas faculdades de uso, gozo e disposição limitados. Por conseguinte, apresenta-se incompatível exigir que o titular aguarde semanas ou meses para garantir o exercício pleno dos direitos decorrentes de sua propriedade.

Todavia, o possuidor que não sofre esbulho não poderá propor a ação de restituição de posse, uma vez que não poderá restituir-se e usufruir da fração temporal de outro proprietário. No mesmo sentido, o proprietário que não sofre a turbação em sua posse, ou seja, durante seu turno, não poderá ajuizar uma ação de manutenção na posse, visto que não é possível que ele se mantenha em uma posse que não corresponde a sua unidade periódica.

Assim, cabe aos demais multiproprietários apenas o interdito proibitório, com intuito de interromper o esbulho ou a turbação e, por via de consequência, a ameaça sobre sua posse.

No entanto, conforme afirma Adroaldo Furtado Fabrício (GONÇALVES, 2019, p. 137), o possuidor que se dirige ao Poder Judiciário em busca de amparo contra o ato ofensivo de sua posse pretende interromper a ação e fazer cessar a moléstia. 0 pedido, então, será sempre o mesmo: a proteção possessória.

Na qualidade de possuidor indireto, portanto, o coproprietário guarda a tutela possessória do caput e do $\S 1^{\circ}$ do art. 1.210 do Código Civil contra moléstias que vir a sofrer.

Portanto, faz-se necessário reconhecer a legitimidade ad causam do titular da multipropriedade para intentar ações em defesa da propriedade e da posse, vez que é tanto proprietário como possuidor da coisa.

Todavia, há de se diferenciar legitimidade de interesse de agir. Este deve ser examinado sob a perspectiva do binômio necessidade e utilidade do provimento jurisdicional. Ou seja, o processo deve ser um meio de propiciar ao demandante um resultado mais favorável do que aquele em que ele se encontra e, ao mesmo tempo, ser encarado como a última forma de solução do conflito.

É possível que o proprietário, apesar de possuir legitimidade ad causam, não preencha o requisito do interesse de agir, imprescindível para postular em juízo (art. 17 do Código de Processo Civil).

O negócio jurídico que institui o regime de time-sharing objetiva a divisão da propriedade na esfera temporal da coisa, entre os sujeitos que o celebraram. A relação entre os multiproprietários é fundada na confiança de que haverá respeito recíproco entre os titulares, principalmente no que se refere à conservação do imóvel e sua utilização apenas no espaço temporal convencionado.

O terceiro que pratica esbulho, turbação ou ameaça é estranho à relação firmada entre os titulares, não existindo garantia de que a moléstia da posse será interrompida na fração de tempo seguinte, fato que causa um justo receio em todos os proprietários. 
Assim, mesmo que a moléstia da posse não esteja ocorrendo na unidade periódica do titular, é imperativo reconhecer, além da legitimidade ad causam inerente a sua qualidade de proprietário e possuidor indireto, seu interesse de agir.

Nesse contexto, surge o questionamento se nas ações possessórias propostas por proprietário do time-sharing, existe ou não a necessidade de formação de um litisconsórcio ativo, o que equivale a perguntar, em termos processuais, se a propositura da ação possessória se dá por meio de litisconsórcio facultativo ou necessário.

O litisconsórcio necessário, ao contrário do facultativo, está diretamente atrelado à indispensabilidade da presença de todos os sujeitos - in casu, todos os multipriprietários do imóvel - no polo ativo da demanda.

Segundo Fredie Didier Jr. (2017, p. 513), o litisconsórcio será necessário em duas situações, conforme art. 114 do Código de Processo Civil: se unitário passivo, ou quando assim o dispuser expressamente a lei.

O autor afirma que, via de regra, não há litisconsórcio ativo necessário, pois o direito de acesso à justiça, tendo por fundamento a faculdade de ir a juízo, não pode depender da vontade de outrem.

Sob ótica diversa, entendem Nelson Nery Jr. e Rosa Maria Barreto Boriello de Andrade Nery (2017, p. 518) que existe sim um litisconsórcio ativo necessário. Todavia, aceitam a possibilidade de uma só pessoa demandar, contanto que inclua no polo passivo da relação jurídica aquele que deveria ser seu litisconsorte ativo.

José Manoel de Arruda Alvim Neto (2016, p. 86) apresenta como solução a convocação de quem deveria ser litisconsorte necessário ativo para compor a lide. Desta forma, poderá: integrar o polo ativo; ocupar o polo passivo, se desejar defender interesse contrário ao do autor; ou permanecer inerte, situação em que não participará de nenhum dos polos da demanda, porém será atingido pela coisa julgada da mesma forma.

No âmbito da multipropriedade, frise-se, todos os titulares são de fato proprietários, possuidores diretos da unidade periódica e possuidores indiretos quando não estão usufruindo da coisa (ALARCÓN e ALARCÓN, 1995, p. 20). Logo, a natureza da relação jurídica poderia justificar a existência do litisconsórcio necessário ativo, prezando pela eficácia da sentença em relação a todos os sujeitos que a integram, conforme o art. 114, in fine, do Código de Processo Civil.

Pois bem. Esse modelo de fracionamento da propriedade, apesar de também pressupor a existência de múltiplos proprietários para uma mesma coisa, é diferenciado quando comparado ao exercício tradicional da posse por duas ou mais pessoas.

No regime de composse, a lei processual civil exige a concordância do outro titular para a propositura da demanda. 0 caput do art. 73 do Código de Processo Civil prescreve que "o cônjuge necessitará do consentimento do outro para propor ação que verse sobre direito real imobiliário, salvo quando casados sob o regime de separação absoluta de bens", sendo a participação do cônjuge nas ações possessórias indispensável somente nas hipóteses de composse ou de ato por ambos praticado, conforme $\S 2^{\circ}$ do art. 73 . 
Os cônjuges exercem a posse sobre a mesma coisa, isto é, dividem espacialmente o imóvel e as faculdades inerentes à propriedade no mesmo período de tempo, inclusive o poder de defesa da posse por meio de interditos possessórios ou da autotutela.

É vedado ao compossuidor, então, praticar ações que prejudiquem o exercício dos atos possessórios pelo outro titular, conforme art. 1.199 do Código Civil, incluindo-se aqui a propositura de ações possessórias: "Art. 1.199. Se duas ou mais pessoas possuírem coisa indivisa, poderá cada uma exercer sobre ela atos possessórios, contanto que não excluam os dos outros compossuidores".

Por outro lado, no time-sharing, fraciona-se a coisa em unidades periódicas: cada titular exerce a posse exclusiva sobre uma fração temporal da qual é proprietário, de modo que não há divisão espacial da coisa (FERNÁNDEZ, 2015).

Enquanto um proprietário está na posse direta do imóvel, exercendo todas as faculdades inerentes à propriedade, os demais exercem a posse indireta sobre a coisa, tendo em vista os desdobramentos da posse decorrentes do art. 1.197 do Código Civil.

Diferentemente da composse, há limitação do exercício da posse pelos titulares, resultante do instrumento de instituição ou da convenção de condomínio em multipropriedade por eles firmado. As faculdades de usar e fruir são restritas àquele que está legitimamente exercendo o efetivo domínio decorrente do seu turno.

A posse direta, todavia, não obsta o exercício da indireta, de tal forma que os possuidores podem defender sua posse de maneira autônoma contra as moléstias praticadas, independentemente dos demais titulares da coisa.

Assim, por se tratarem de regimes diferentes de posse, aplicam-se regras distintas, de modo que na multipropriedade, ao contrário do que ocorre na composse, o litisconsórcio será facultativo.

Em se tratando do regime da multipropriedade imobiliária, o mais apropriado é o posicionamento de José Manoel de Arruda Alvim Neto (2016, p. 86), uma vez que deixa a critério do proprietário averiguar se há interesse na participação no polo ativo da demanda, ou se prefere permanecer inerte diante da lide em questão.

Neste caso, não se pode admitir que o direito de ação dos demais titulares, especialmente daquele que está diante de uma atual limitação das suas faculdades decorrentes da propriedade, esteja condicionado à atuação daquele que preferiu não participar do litígio.

Seja qual for a decisão do proprietário - integrar ou não a relação processual -, imperativa se faz sua intimação, a fim de que seja respeitado o contraditório. Desta forma, garante-se sua participação e sua informação, sem obriga-lo a demandar e, ainda, sem condicionar o direito de ação do titular molestado à vontade e a uma potestade dos demais.

Portanto, a imposição do litisconsórcio ativo necessário no âmbito da multipropriedade se dá apenas na ocasião em que existe composse na unidade periódica, ou seja, quando os cônjuges são proprietários e exercem a posse sobre uma mesma fração temporal; ou em situações hipotéticas em que pessoas sem vínculo matrimonial ou convivencial são proprietários do turno; ou, ainda, em situações de direito hereditário de representação. Entre eles, aplica-se a regra do $\S 2^{\circ}$ do art. 73 do Código de Processo Civil, de modo que um não pode 
demandar sem o consentimento do outro. Entre os demais multiproprietários, no entanto, não há que se falar em litisconsórcio necessário ativo.

Outro ponto de controvérsia consiste em averiguar se o juiz, diante da multipropriedade imobiliária, poderá impor a introdução dos demais multiproprietários se julgar oportuna a presença deles no processo.

Apesar do parágrafo único do art. 115 do Código de Processo Civil tratar apenas do litisconsórcio passivo necessário, a determinação pelo juiz também pode incidir na modalidade ativa, mesmo que observada com menor frequência.

Há na literatura jurídica quem reconheça que a intervenção iussu iudicis está relacionada com a ordem de integração obrigatória, seja no polo passivo, seja no lado ativo da demanda. Assume-se aqui, no entanto, a posição de Fredie Didier Jr. (2017, p. 594-597), segundo a qual o litisconsórcio necessário é um caso típico desta modalidade de intervenção, porém não se limita a ele.

O reconhecimento da possibilidade de intervenção iussu iudicis além dos casos expressos no dispositivo legal - ou seja, de maneira atípica - se mostra conveniente para concretizar os princípios da adequação, da duração razoável do processo, da eficiência, do contraditório e da igualdade (DIDIER JR., 2017, p. 596), bem como a segurança jurídica e a economia processual.

Então, conforme se posicionou o STJ no Recurso Especial n ${ }^{\circ} 1.170 .028 / S P$, é dada "ciência ao terceiro da demanda existente, permitindo-lhe o ingresso na lide na condição que escolher, resguardando-o, assim, dos efeitos da sentença e garantindo a efetividade do provimento judicial. Não se presta, pois, a impor ao terceiro o dever de demandar" (STJ, REsp. nº 1.170.028/SP, $4^{\text {a }}$ Turma, Rel. Min. Raul Araújo, julgado em 15/08/2017).

O regime de multipropriedade cria uma relação material entre os multiproprietários, de maneira que a ação judicial e a coisa julgada ocasionarão consequências para todos os titulares da coisa. Nesse sentido, entende-se por "terceiro" os coproprietários do imóvel que não tinham conhecimento da demanda.

Assim, pode o juiz determinar a intervenção do proprietário que possivelmente será afetado pela coisa julgada mesmo nos casos em que não há formação de um litisconsórcio necessário, e sim facultativo. Garante-se ao titular, nessa condição, o exercício da liberdade fundamental de demanda, sem que lhe seja imposta obrigação de integrar a relação processual (DIDIER JR., 2017, p. 594-597).

O caput do art. 564 do Código de Processo Civil prescreve que, concedido ou não o mandado liminar de manutenção ou reintegração, o autor promoverá a citação do réu para, querendo, contestar a ação. Assim, após a citação, o procedimento especial se converte em comum.

Estando diante de um procedimento comum, aplicam-se às ações possessórias as mesmas regras das demais ações judiciais. Dessa forma, o juiz tem o dever de intimar todos os titulares do condomínio multiproprietário para assumirem uma posição no processo.

A partir desse momento, portanto, a intervenção dos demais multiproprietários passa a ser obrigatória, para que o pronunciamento judicial, que possivelmente repercutirá na esfera patrimonial de todos os titulares, possa produzir efeitos também em face deles. 
Pois bem. É possível que se deem, ainda, ações possessórias entre multiproprietários. As moléstias da posse podem ser praticadas tanto por terceiros ao negócio multiproprietário - os chamados penitus extranei - quanto pelos próprios multiproprietários e pelo administrador. Diante disso, é facultado aos titulares e ao administrador o uso da heterotutela possessória ou da autotutela possessória, garantindo-se a ampla defesa da posse.

Gustavo Tepedino (1993, p. 125) afirma que "na qualidade de possuidor indireto, pode o multiproprietário fazer recurso das ações possessórias para a proteção do solo sobre o qual incide sua fração ideal contra eventuais lesões de terceiros ou de outros condôminos".

Assim, v.g., o proprietário que é privado de exercer sua posse por ação de outro titular, que pratica esbulho, pode ser restituído na sua posse a partir da propositura de ação possessória.

No entanto, não há desdobramento da posse entre o possuidor direto e indireto se verificada a ocorrência de moléstias, já que é imprescindível que a posse seja autorizada para que haja distribuição de poderes, isto é, deve ser derivada de negócio jurídico, requisito que não é preenchido na hipótese de esbulho, turbação ou ameaça.

Então, o titular que pratica a moléstia não detém posse legítima da coisa, permitindo a defesa possessória pelos outros multiproprietários por meio dos interditos.

A propositura de ação possessória pode acarretar o arbitramento de multa, além da cumulação do pedido possessório do autor ao de condenação em perdas e danos e indenização dos frutos, conforme o art. 555 do Código de Processo Civil.

Uma hipótese de condenação pecuniária ocorre nas ações de interdito proibitório, ou seja, ações que visam a evitar a concretização da ameaça. Nesta situação, a pena imposta pretende alertar ao demandado sobre as consequências que a pratica do esbulho ou turbação causarão a ele, servindo para desestimular o ato.

Ademais, caso o proprietário ultrapasse o tempo de permanência no imóvel previsto no instrumento de instituição ou na convenção de condomínio em multipropriedade, outra multa deve ser aplicada a ele. Se recorrente, poderá, ainda, perder temporariamente o direito de utilização da coisa no período correspondente à sua fração de tempo.

Isso porque o uso do imóvel exclusivamente durante o período correspondente à sua fração de tempo e a desocupação até o dia e hora fixados são obrigações dos coproprietários elencadas nos incisos VII e VIII do art. 1.358-J do Código Civil.

Portanto, aquele que comete atos que configuram esbulho, turbação ou ameaça está sujeito ao pagamento de duas multas: uma arbitrada judicialmente e outra originária do acordo condominial firmado entre os titulares.

Tendo em vista que as regras de utilização do imóvel e as frações de tempo correspondente de cada proprietário estão dispostas na instituição ou na convenção de condomínio em multipropriedade, registre-se que as consequências enumeradas no dispositivo legal consistem em penalidades com natureza de inadimplemento contratual.

Ou seja, a multa é fixada de maneira antecipada, a fim de cobrir as perdas e danos na hipótese de inobservância dos deveres fixados na relação jurídica. 
De modo diverso, a multa fixada no juízo possessório consiste em um instrumento de coerção ou punição, tendo por objetivo o cumprimento da decisão judicial ou impedir que a moléstia venha a ser praticada.

Tanto o terceiro, sujeito que nenhuma relação possui com o condomínio multiproprietário, quanto o administrador e os titulares do imóvel, estão sujeitos a esta condenação pecuniária.

Por outro lado, aquela decorrente do inadimplemento contratual é oponível apenas aos coproprietários inseridos no regime de time-sharing, que se tornaram responsáveis pelo descumprimento das obrigações dispostas convenção pactuada.

Então, no caso de moléstias da posse praticadas pelos próprios multiproprietários, haverá o somatório das multas contratual e coercitiva. Considerando-se que elas possuem naturezas diferentes, não há que se falar na existência de bis in idem decorrente dessa cumulação.

\section{CONCLUSÃO}

Essa pesquisa se desenvolveu investigando respostas ao questionamento de qual coproprietário seria parte legítima para a proteção possessória nos casos de moléstias praticadas por outro coproprietário ou por terceiro. A dúvida decorria do fato de a utilização do imóvel na multipropriedade se dar em períodos pré-determinados.

Com base no desdobramento da posse, decorrente do negócio jurídico entre os multiproprietários, constatou-se que todos guardam a qualidade de possuidores, mesmo que não estejam exercendo o uso do imóvel (hipótese em que terão a posse indireta da coisa). Por conseguinte, todos os multiproprietários podem invocar a proteção possessória, ainda que não estejam usufruindo da sua parcela temporal de uso.

Quanto à possibilidade de prática de moléstia entre os multiproprietários, verificou-se que existe a possibilidade de esbulho, turbação e ameaça entre eles. A investigação revelou que o coproprietário que não está no exercício da sua fração temporal é apenas titular da posse indireta, devendo se abster de molestar para permitir que os outros multiproprietários exerçam a posse direta da coisa. Daí que foi possível confirmar a hipótese de que o coproprietário pode obstar o exercício da posse por outro coproprietário, se praticar alguma limitação ilícita.

Diante do desdobramento da posse, a posse direta não obsta o exercício da indireta, de forma que os possuidores podem defender sua posse de maneira autônoma. Trata-se, portanto, de um litisconsórcio facultativo.

Assim, da forma como foi proposto, a partir das premissas construídas por meio da análise das moléstias e desdobramento da posse, foi possível confirmar a hipótese para o problema do fracionamento temporal na posse da multipropriedade e propor medidas para enfrentar as questões problemáticas que circundavam a legitimidade ad causam para exercício da tutela interdital na multipropriedade. 


\section{REFERENCIAS}

ALARCÓN, Jose Antonio Mora; ALARCÓN, Luis Miguel Mora. Manual práctico sobre comunidades de propietarios y multipropiedad. Madrid: Edisofer, 1995.

ALPA, Guido. II recepimento della direttiva comunitaria in materia di multiproprietà un'analisi comparativa. In: Europa e Diritto Privato, n. 1, p. 193-220, 1998.

ARRUDA ALVIM NETO, José Manoel de. Novo contencioso cível no CPC/2015. São Paulo: Revista dos Tribunais, 2016.

AVENDAÑO VALDEZ, Jorge. Posesión ilegítima o precaria. In: Themis - Revista de Derecho, n. 4, Lima, p. 59-63, 1986.

BARDAJÍ, María Dolores Díaz-Ambrona. Apuntes sobre la multipropiedad. In: Revista Crítica de Derecho Inmobiliario, año nº 76, n. 658, p. 1429-1450, 2000.

BERNAT, Pedro A. Munar. Presente y futuro de la multipropiedad. Madrid: Tecnos, 1992.

CASTRO, Luis Martínez Vázquez de. La multipropiedad inmobiliaria. Madrid: Reus, 1989.

CERVALE, María Cristina. La propriera "plurale": un itinerario tra condominio e multiproprietà. In: Rassegna di Diritto Civile, n. 2, p. 358-387, 2014.

COSTA, Dilvanir José da. 0 sistema da posse no Direito Civil. In: Revista de Informação Legislativa, Brasília, a. 35, n. 139, p. 109-117, jul./set. 1998.

DE COS, Gabriela Mazorra. Claves de la "multipropiedad": obligaciones para los propietarios. In: Inmueble: Revista del Sector Inmobiliario, n. 114, p. 44-52, 2011.

DIDIER JR., Fredie. Curso de direito processual civil: Introdução ao Direito Processual Civil, Parte Geral e Processo de Conhecimento. Salvador: Juspodivm, 2017.

FERNÁNDEZ, María José Azaustre. El aprovechamiento de bienes por tiempo alterno en Derecho Romano. In: Revista General de Derecho Romano, n. 25, 2015.

FERRETTI, Paolo. II possesso tra animus e corpus: da Labeone a Paolo. In: FERRETTI, Paolo; FIORENTINI, Mario (a cura di). Formazione e trasmissione del sapere: diritto, letteratura e società. VI incontro tra storici e giuristi dell'antichità. Trieste: EUT Edizioni Università di Trieste, p. 11-36, 2020.

GONÇALVES, Carlos Roberto. Direito Civil Brasileiro: Direito das Coisas. São Paulo: Saraiva, 2019.

GONÇALVES, Marcus Vinícius Rios. Dos vícios da posse. 4. ed. Porto Alegre: Juarez de Oliveira, 2008.

IHERING, Rudolf von. Fundamento dos interditos possessórios. Tradução de Adherbal de Carvalho. Bauru: Edipro, 2007.

LINS, Edmundo Pereira. Ensaio sobre a posse - Capítulo III. In: Revista da Faculdade de Direito da UFMG, vol. 9, p. 155-174, jan. 1914.

MACCORMACK, Geoffrey. Iusta and Iniusta Possessio. In: Tijdschrift voor Rechtsgeschiedenis / Revue d'Histoire du Droit / The Legal History Review, vol. 42, issue 1, p. 71-80, 1974.

MARQUES, Cláudia Lima. Contratos de time-sharing en Brasil y la protección de los consumidores: crítica al derecho civil en tiempos postmodernos. In: Estudios Sobre Consumo, n. 45, p. 23-40, 1998.

MARQUES, Norma Jeane Fontenelle. A desjudicialização como forma de acesso à Justiça. Disponível em: https:// ambitojuridico.com.br/cadernos/direito-processual-civil/a-desjudicializacao-como-forma-de-acesso-a-justica/\#_ftn2. Acesso em: 18 abr. 2020.

MENDO, Pilar Muñoz. ¿Arrendamiento de Temporada, Estancia Turística o Time Sharing? In: Diario La Ley, n. 7297 , 2009.

NEVES, Daniel Amorim Assumpção. Manual de direito processual civil. Salvador: Juspodivm; Versão Digital: Viva, 2016. 
OLIVEIRA, Carlos Eduardo Elias de. Análise detalhada da multipropriedade no Brasil após a Lei n 13.777/2018: pontos polêmicos e aspectos de registros públicos. Disponível em: http://genjuridico.com.br/2019/03/21/analise-detalhada-da-multipropriedade-no-brasil-apos-a-lei-no-13-777-2018-pontos-polemicos-e-aspectos-de-registros-publicos/. Acesso em: 17 jan. 2020a.

OLIVEIRA, Carlos Eduardo Elias de. Considerações sobre a recente Lei da Multipropriedade. Disponível em: https:// flaviotartuce.jusbrasil.com.br/artigos/661740743/consideracoes-sobre-a-recente-lei-da-multipropriedade. Acesso em: 13 jan. 2020b.

PAIVA, Moisés Emidio de. Multipropriedade: conceito, dinâmica e funcionamento. Disponível em: https://jus.com. br/artigos/76557/multipropriedade-conceito-dinamica-e-funcionamento. Acesso em: 11 jan. 2020.

PENTEADO, Luciano de Camargo. Direito das Coisas. 3. ed. São Paulo: Revista dos Tribunais, 2014.

PERES, Sandra Ferreira de Carvalho. A controvérsia do direito real da multipropriedade imobiliária no direito privado. 2018. 125 f. Monografia (Especialização) - Curso de Direito, Escola da Magistratura do Estado do Rio de Janeiro, Rio de Janeiro, 2018.

PÉREZ, Jorge Rodríguez; CALERO, Antonio Díaz-Flores. La multipropiedad. Las Palmas: J. Rodríguez, 1992.

RICCOBONO, Salvatore. Zur Terminologie der Besitzverhältnisse (Naturalis possessio, civilis possessio, possessio ad interdicta). Ristampa a cura di Pierangelo Buongiorno. In: Rivista di Diritto Romano, vol. XII, p. 1-32, 2012.

SANDRI, Adelle Ribeiro Coelho. A figura do time-sharing em perspectiva de direito comparado - Portugal e Brasil. In: Revista de Direito Imobiliário, n. 76, p. 79-116, 2014.

SARAIVA, Bruno de Sousa. Uma Análise Jurídica da Multipropriedade Imobiliária, vol. 9. Ceará: Themis - Revista da Escola Superior da Magistratura do Ceará, 2011.

SILVESTRE, Gilberto Fachetti. As alterações da Lei nº. 13.465/2017 na usucapião especial urbana coletiva: questões materiais e processuais. In: Revista Direito da Cidade, vol. 11, n. 2, p. 337-367, 2019.

SIQUEIRA, Marcelo Sampaio; SIQUEIRA, Natércia Sampaio. A perda da multipropriedade imobiliária por usucapião. In: Revista Jurídica da FA7, vol. 14, n. 2, p. 65-80, 2017.

SMORTO, Guido. La multiproprietà e la tutela dei consumatori: il recepimento della direttiva 94/47/CE. In: Europa e Diritto Privato, n. 1, p. 279-306, 1999.

TEPEDINO, Gustavo. A nova Lei da Multipropriedade Imobiliária. Disponível em: https://rbdcivil.ibdcivil.org.br/ rbdc/article/view/359/268. Acesso em: 12 jan. 2020a.

TEPEDINO, Gustavo. Aspectos atuais da multipropriedade imobiliária. Disponível em: http://www.tepedino.adv. br/tep_artigos/aspectos-atuais-da-multipropriedade-imobiliaria/. Acesso em: 11 jan. $2020 \mathrm{~b}$.

TEPEDINO, Gustavo. Multipropriedade imobiliária. São Paulo: Saraiva, 1993.

TRANCHANT, Laetitia. Bail à réhabilitation usufruit locatif social, multipropriété. In: Revue de Droit Immobilier, année 36, n. 5, p. 276-281, 2014.

VENOSA, Sílvio de Salvo. Multipropriedade (time sharing). Disponível em: https://www.migalhas.com.br/ depeso/295907/multipropriedade-time-sharing. Acesso em: 10 jan. 2020.

ZAIM, Miguel. Multipropriedade - Uma nova modalidade de condomínio. Disponível em: https://jus.com.br/artigos/70551/multipropriedade-uma-nova-modalidade-de-condominio. Acesso em: 13 jan. 2020

Recebido/Received: 14.07.2020.

Aprovado/Approved: 25.10.2020. 